\title{
BCL9 wt Allele
}

National Cancer Institute

\section{Source}

National Cancer Institute. BCL9 wt Allele. NCI Thesaurus. Code C52490.

Human BCL9 wild-type allele is located in the vicinity of $1 \mathrm{q} 21$ and is approximately $85 \mathrm{~kb}$ in length. This allele, which encodes B-cell lymphoma 9 protein, may be involved in the regulation of Wnt protein mediated signaling. Altered expression of this gene, which is the result of a translocation $\mathrm{t}(1 ; 14)(\mathrm{q} 21 ; \mathrm{q} 32)$, is associated with acute lymphoblastic leukemia. 